\title{
Iron Deficiency is Not Associated with Increased Blood Cadmium in Infants
}

\author{
Jung-Hun Park', Sangkyu Park² and Yangho Kim"
}

\begin{abstract}
Objectives: To determine whether blood cadmium concentration is elevated in iron-deficient infants.

Methods: Blood cadmium and serum ferritin concentrations, serum iron/total iron-binding capacity (Fe/TIBC) and complete blood counts were measured in 31 iron deficient and 36 control infants, aged 6-24 months. All 31 iron-deficient infants received iron supplementation for 1-6 months.

Results: Blood cadmium concentrations were measured again in 19 of the iron deficient infants after their ferritin levels returned to the normal range. The mean blood cadmium concentration did not differ significantly in iron deficient and control infants. The mean blood cadmium concentration in the 19 iron-deficient infants was not significantly altered by ferric hydroxide treatment, while their hemoglobin, ferritin, and Fe/TIBC (\%) concentrations were significantly higher after than before treatment.
\end{abstract}

Conclusion: These findings indicate that iron deficiency does not increase blood cadmium concentrations in infants, in contrast with the effects of iron deficiency on manganese and lead concentrations.

Keywords: Iron, Deficiency, Cadmium, Anemia

\section{Introduction}

Iron deficiency affects approximately one-third of the world's population [1], occurring most frequently in infants aged 6 months to 3 years due to their rapid growth and inadequate dietary intake of iron [2]. Iron-deficiency anemia has been associated with poor cognitive development, poor motor development and behavioral problems $[3,4]$.

Because iron is absorbed via mechanisms similar to those of other divalent metal ions, including cadmium, manganese, and lead, a dietary deficiency in iron can lead to excess absorption of cadmium, a widespread toxicant with detrimental effects on health. Indeed, iron deficiency has been found to predispose animals to cadmium toxicity by increasing gastrointestinal cadmium absorption [5-10]. Several studies have suggested an association between iron status and blood cadmium concentration in adults, especially pre-menopausal women [11-20], whereas few studies have been conducted in children [12,21-24]. We assessed whether blood cadmium concentrations are

\footnotetext{
* Correspondence: yanghokm@nuri.net

'Department of Occupational and Environmental Medicine, Ulsan University Hospital, University of Ulsan College of Medicine, 290-3 Cheonha-Dong, Dong-Gu, Ulsan 682-060, South Korea

Full list of author information is available at the end of the article
}

higher in iron-deficient than in control infants, and whether treatment of the former with iron supplements affects cadmium concentrations.

\section{Materials and methods Materials}

Thirty one infants with iron deficiency (serum ferritin concentration $<15 \mu \mathrm{g} / \mathrm{L}$ ), ranging in age from 6 months to 2 years, were selected from infants being treated at an ambulatory pediatric hematology clinic at Ulsan University Hospital, Ulsan, South Korea. Thirty-six healthy, age- and sex-matched control subjects, with serum ferritin concentrations higher than $15 \mu \mathrm{g} / \mathrm{L}$, were selected from among the infants visiting a general pediatric clinic in the same hospital. Subjects were excluded if they were delivered preterm or at low birth weight; had a history of any disease, or had concurrent acute or chronic infection or inflammation; or if their parents had a history of occupational exposure to cadmium. All 31 iron-deficient infants were treated with ferric hydroxide-polymaltose complex $\left(6 \mathrm{mg} / \mathrm{kg} \mathrm{Fe}^{3+} /\right.$ day $)$ for $1-$ 6 months. Blood cadmium concentrations were determined in all control subjects and in all iron-deficient subjects prior to iron supplementation. Blood cadmium concentrations 
were assessed again in 19 iron-deficient infants after their ferritin concentrations returned to the normal range; the other 12 iron-deficient infants were lost to follow up. Parents of infants in both groups provided written informed consent, and the study protocol was approved by the institutional review board of Ulsan University Hospital.

\section{Laboratory testing}

A questionnaire was administered to the parents of each infant to obtain basic perinatal information, along with information on breast feeding and nutrition. Heparinized venous blood samples were obtained from each infant, and blood count, hemoglobin concentration, hematocrit, serum ferritin concentration, and serum iron/total ironbinding capacity (Fe/TIBC) were measured. Iron deficiency was defined as serum ferritin $<15 \mu \mathrm{g} / \mathrm{L}$ [25].

\section{Cadmium determination in whole blood}

Blood cadmium concentration was determined by flameless graphite furnace atomic absorption spectrophotometry (AAS) (Spectra AA880-GTA 100, Varian, Australia), using the standard addition method. Briefly, aliquots $(0.1 \mathrm{ml})$ of blood were diluted 20 fold with $0.1 \%$ (v/v) Triton X-100, and $15-\mu \mathrm{L}$ samples were injected into the graphite furnace. All blood cadmium analyses were carried out in the Ulsan University Hospital laboratory, which had passed the Quality Assurance Program (for cadmium) operated by the Korea Occupational Safety and Health Agency. The detection limit for blood cadmium in the present study was $0.09 \mu \mathrm{g} / \mathrm{L}$. Two samples had cadmium levels below the detection limit; in those samples, we considered the level in the sample to be the detection limit divided by the square root of 2 [26].

\section{Statistical analyses}

Blood cadmium levels were natural log-transformed because their distributions were skewed, and the geometric means (GMs) are presented. Significant differences in the means of continuous variables between iron-deficient and control infants were determined using Student's t-tests. Differences in the proportion of male infants between these groups were determined using the chi-square test. Significant differences in the means of variables before and after iron therapy were determined using paired t tests. SPSS (v14) software was used for all statistical analyses, and a $P$ value $<0.05$ was considered significant.

\section{Results}

Age and gender distribution were similar in the irondeficient and control groups, as were their GM blood cadmium concentrations. However, hemoglobin concentrations, hematocrit levels, and serum ferritin levels differed significantly in the two groups (Table 1).
Table 1 Demographic, clinical and laboratory features of the study subjects

\begin{tabular}{lccc}
\hline Group characteristics & $\begin{array}{c}\text { Iron-deficient } \\
\text { infants }(\mathbf{n}=\mathbf{3 1})\end{array}$ & $\begin{array}{c}\text { Control } \\
(\mathbf{n}=\mathbf{3 6})\end{array}$ & $\boldsymbol{P}$ value \\
\hline Age (months) & $12.0 \pm 3.7$ & $11.9 \pm 4.1$ & 0.867 \\
Male (\%) & 65.6 & 52.8 & 0.330 \\
Breast feeding (months) & $10.3 \pm 3.4$ & $6.3 \pm 4.9$ & $<0.001$ \\
Cadmium $(\mu \mathrm{g} / \mathrm{L})^{*}$ & $0.56(0.06-1.20)$ & $0.53(0.06-1.84)$ & 0.724 \\
Hemoglobin $(\mathrm{g} / \mathrm{dL})$ & $10.49 \pm 1.84$ & $11.83 \pm 1.02$ & 0.001 \\
Hematocrit $(\%)$ & $32.70 \pm 4.08$ & $35.02 \pm 2.60$ & 0.008 \\
Ferritin $(\mu \mathrm{g} / \mathrm{L})$ & $7.4 \pm 3.0$ & $39.1 \pm 23.8$ & $<0.001$ \\
Fe $(\mu \mathrm{g} / \mathrm{dL})$ & $39.09 \pm 29.56$ & $47.14 \pm 27.79$ & 0.255 \\
TIBC $(\mu \mathrm{g} / \mathrm{dL})$ & $413.19 \pm 53.18$ & $351.80 \pm 47.07$ & $<0.001$ \\
Fe/TIBC $(\%)$ & $10.2 \pm 8.6$ & $13.7 \pm 8.5$ & 0.091 \\
\hline
\end{tabular}

Results reported as mean $\pm S D$ *geometric mean (range).

Mean duration of breast feeding was longer in irondeficient than in control infants. All the iron-deficient infants were treated with an iron supplement, and 19 were tested again for blood cadmium concentrations after their ferritin concentrations reached the normal range. The GM blood cadmium concentration in these 19 infants was not significantly altered by ferric hydroxide treatment, while their hemoglobin, ferritin, and Fe/TIBC (\%) levels were significantly higher after than before treatment (Table 2).

\section{Discussion}

Cadmium concentrations have been reported to increase as iron stores decrease in premenopausal women [11-20]. However, no association between iron deficiency and elevated cadmium levels was observed in menopausal women [27-29] or in men [19,30], and few studies to date have analyzed the association between iron deficiency and elevated cadmium levels in children. Furthermore the studies that have been performed in children have yielded conflicting results. Some studies reported an association [21,24] between iron deficiency and cadmium, whereas others found no such association [22,23], and one study reported an

Table 2 Laboratory features of iron-deficient infants before and after iron therapy

\begin{tabular}{lccc}
\hline Group characteristics & $\begin{array}{c}\text { Before iron } \\
\text { therapy }(\mathbf{n}=19)\end{array}$ & $\begin{array}{c}\text { After iron } \\
\text { therapy }(\mathbf{n}=19)\end{array}$ & $\boldsymbol{P}$ value \\
\hline Cadmium $(\mu \mathrm{g} / \mathrm{L}) *$ & $0.58(0.06-1.40)$ & $0.47(0.06-1.38)$ & 0.529 \\
Hemoglobin $(\mathrm{g} / \mathrm{dL})$ & $10.49 \pm 1.75$ & $12.38 \pm 0.85$ & 0.001 \\
Hematocrit $(\%)$ & $32.77 \pm 3.80$ & $36.87 \pm 2.24$ & 0.002 \\
Ferritin $(\mu \mathrm{g} / \mathrm{L})$ & $7.03 \pm 3.16$ & $20.83 \pm 7.04$ & $<0.001$ \\
Fe $(\mu \mathrm{g} / \mathrm{dL})$ & $35.11 \pm 25.30$ & $64.68 \pm 36.61$ & 0.006 \\
TIBC $(\mu \mathrm{g} / \mathrm{dL})$ & $416.68 \pm 46.50$ & $365.89 \pm 52.79$ & $<0.001$ \\
Fe/TIBC $(\%)$ & $8.8 \pm 6.8$ & $17.9 \pm 9.5$ & 0.001 \\
\hline
\end{tabular}

Results reported as mean \pm SD and compared by paired t tests. * geometric mean (range) Iron-deficient infants were followed-up after 1-6 months of treatment with ferric hydroxide-polymaltose complex ( $6 \mathrm{mg} / \mathrm{kg} \mathrm{Fe}^{3+}$ per day). 
association between ferritin and cadmium concentrations in female adolescents only [12]. To our knowledge, our study is the first to assess the association between iron deficiency and cadmium concentration in infants, finding that the two were not associated. In contrast, assessment of the same study subjects showed that iron deficiency was associated with increased blood lead and manganese concentrations [31,32]. The GM of blood cadmium $(0.54 \mu \mathrm{g} / \mathrm{L})$ in all infants in the present study was similar to that of adults aged $20-29$ years $(0.56 \mu \mathrm{g} / \mathrm{L})$, and lower than that of adults aged 20 years and older $(0.93 \mu \mathrm{g} / \mathrm{L})$ [20].

Our finding, that iron deficiency and cadmium concentration were not associated in infants, is compatible with some previous studies in children $[22,23]$ but not with others $[21,24]$. These discrepancies may be due in part to differences in cadmium exposure levels or the age distribution of study subjects. For example, the two studies finding an association between iron deficiency and cadmium in children involved subjects living in an area of Turkey with heavy air pollution [21] and in children with blood cadmium concentrations more than 6-fold higher than in our study cohort [24]. The subjects assessed in the present study consisted of infants living in a non-polluted area, and with very low blood cadmium concentrations. Furthermore, the subjects in most previous studies included children and/or adolescents, but not infants [12,21-24].

The placenta may act as a partial barrier to fetal exposure to cadmium [33], and only $5-10 \%$ of maternal blood cadmium may be transferred to human milk because of metallothionein binding of cadmium in blood cells [34]. Cadmium concentrations usually increase with age $[20,30,35,36]$. Thus, infants may have smaller chances of exposure to cadmium, and may not show increased blood cadmium concentrations associated with iron deficiency. In contrast, lead can pass the placental barrier and is present in more widespread sources to which infants may be exposed than cadmium, resulting in lead being more easily absorbed by infants with iron deficiency [32]. Manganese, an essential element, is abundant in foods, and is easily absorbed in individuals with iron deficiency [37-40].

Our results suggest that iron deficiency is associated with prolonged breast feeding in infants, a result consistent with findings showing that prolonged breast feeding was associated with iron deficiency $[41,42]$. Since not all infants in the present study who received prolonged breast feeding were iron deficient, differences in the iron status of these infants may depend on whether they receive iron-rich supplementary foods during prolonged breast feeding.

The present study had several limitations. Regarding the method used to measure iron concentration, serum ferritin is an acute-phase reactant that may be artificially elevated in the presence of inflammation [43], a potential confounding factor that we did not rule out (e.g., by adjusting for C-reactive protein, which was not measured). We did, however, exclude infants with acute or chronic inflammation or infection. Second, we did not measure urinary cotinine levels in these infants and did not exclude cadmium exposure due to passive smoking. Third, the lack of statistical significance might be due to the small sample size of the present study population. In particular, 12 iron-deficient infants were lost to follow up. The GM blood cadmium concentration in the remaining 19 infants was mildly decreased by ferric hydroxide treatment, but the difference was not statistically significant. If there had been no infants lost to follow-up, this difference may have reached statistical significance. Further studies with larger sample sizes are needed.

\section{Conclusion}

In conclusion, we have shown here that iron deficiency does not increase blood cadmium concentrations in infants.

\section{Competing interests}

The authors declare that they have no competing interests.

\section{Authors' contribution}

YK, SP, and J-HP contributed to the conception and design of the study. YK is involved in the statistical analysis and interpretation of data. J-HP drafted the manuscript. All authors read and approved the final manuscript.

\section{Author details}

${ }^{1}$ Department of Occupational and Environmental Medicine, Ulsan University Hospital, University of Ulsan College of Medicine, 290-3 Cheonha-Dong, Dong-Gu, Ulsan 682-060, South Korea. ²Department of Pediatrics, Ulsan University Hospital, University of Ulsan College of Medicine, Ulsan, South Korea.

Received: 18 December 2013 Accepted: 5 February 2014 Published: 10 February 2014

\section{References}

1. De Benoist B, McLean E, Egli I, Cogswell M: Worldwide Prevalence of Anaemia1993-2005: WHO Global Database of Anaemia. Technical Report. Geneva: World Health Organization; 2008.

2. Centers for Disease Control and Prevention (CDC): Recommendations to prevent and control iron deficiency in the United States. MMWR 1998, 47(No. RR-3):5

3. Lozoff B: Iron defciency and child development. Food Nutr Bull 2007, 28(Supplement 4):560S-571S.

4. Lozoff B, Beard J, Connor J, Felt B, Georgie M, Schallert T: Long-lasting neural and behavioral effects of iron deficiency in infancy. Nutr Rev 2006, 64(s2):S34-S43.

5. Ragan HA: Effects of iron deficiency on the absorption and distribution of lead and cadmium in rats. J Lab Clin Med 1970, 90(4):700-705.

6. Garrick MD, Dolan KG: An expression system for a transporter of iron and other metals. Methods Mol Biol 2002, 196:147-154.

7. Park JD, Cherrington NJ, Klaassen CD: Intestinal absorption of cadmium is associated with divalent metal transporter 1 in rats. Toxicol Sci 2002, 8(2):288-294.

8. Ryu DY, Lee S, Park J, Choi DW, Klaassen CD, Park JD: Dietary iron regulates intestinal cadmium absorption through iron transporters in rats. Toxicol Lett 2004, 152(1):19-25.

9. Tallkvist J, Bowlus CL, Lönnerdal B: DMT1 gene expression and cadmium absorption in human absorptive enterocytes. Toxicol Lett 2001, 122(2):171-177.

10. Zoller $\mathrm{H}$, Koch RO, Theurl I, Obrist P, Pietrangelo P, Montosi G, et al: Expression of the duodenal iron transporters divalent-metal transporter 1 and ferroportin 1 in iron deficiency and iron overload. Gastroenterology 2001, 120(6):1412-1429. 
11. Åkesson A, Berglund M, Schütz A, Bjellerup P, Bremme K, Vahter M: Cadmium exposure in pregnancy and lactation in relation to iron status. Am J Public Health 2002, 92(2):284-287.

12. Bárány $E$, Bergdahl IA, Bratteby LE, Lundh T, Samuelson G, Skerfving S, et al: Iron status influences trace element levels in human blood and serum. Environ Res 2005, 98(2):215-223.

13. Berglund $M$, Åkesson A, Nermell B, Vahter M: Intestinal absorption of dietary cadmium in women depends on body iron stores and fiber intake. Environ Health Perspect 1994, 102(12):1058-1066.

14. Gallagher CM, Chen JJ, Kovach JS: The relationship between body iron stores and blood and urine cadmium concentrations in US never-smoking, non-pregnant women aged 20-49 years. Environ Res 2011, 111(5):702-707.

15. Kippler M, Ekström EC, Lönnerdal B, Goessler W, Akesson A, El Arifeen S, et al: Influence of iron and zinc status on cadmium accumulation in Bangladeshi women. Toxicol Appl Pharmacol 2007, 222(2):221-226.

16. Kippler M, Goessler W, Nermell B, Ekström EC, Lönnerdal B, El Arifeen S, Vahter M: Factors influencing intestinal cadmium uptake in pregnant Bangladeshi women-a prospective cohort study. Environ Res 2009, 109(7):914-921.

17. Meltzer HM, Brantsaeter AL, Borch-lohnsen B, Ellingsen DG, Alexander J, Thomassen $Y$, et al: Low iron stores are related to higher blood concentrations of manganese, cobalt and cadmium in non-smoking, Norwegian women in the HUNT 2 study. Environ Res 2010, 110(5):497-504.

18. Mijal RS, Holzman CB: Blood cadmium levels in women of childbearing age vary by race/ethnicity. Environ Res 2010, 110(5):505-512.

19. Satarug S, Ujjin P, Vanavanitkun Y, Baker JR, Moore MR: Influence of body iron store status and cigarette smoking on cadmium body burden of healthy Thai women and men. Toxicol Lett 2004, 148(3):177-185.

20. Lee B-K, Kim Y: Iron deficiency is associated with increased levels of blood cadmium in the Korean general population: analysis of 2008-2009 Korean National Health and Nutrition Examination Survey data. Environ Res 2012, 112(1):155-163.

21. Turgut S, Polat A, Inan M, Turgut G, Emmungil G, Bican M, Karakus TY, Genc $\mathrm{O}$ : Interaction between anemia and blood levels of iron, zinc, copper, cadmium and lead in children. Indian J Pediatr 2007, 74(9):827-830.

22. Zhao TT, Chen B, Wang HP, Wang R, Zhang H: Evaluation of toxic and essential elements in whole blood from 0 - to 6-year-old children from Jinan, China. Clin Biochem 2013, 46(7-8):612-616.

23. Choi JW, Kim SK: Relationships of lead, copper, zinc, and cadmium levels versus hematopoiesis and iron parameters in healthy adolescents. Ann Clin Lab Sci 2005, 35(4):428-434.

24. Shah F, Kazi TG, Afridi HI, Kazi N, Baig JA, Shah AQ, Khan S, Kolachi NF, Wadhwa SK: Evaluation of status of trace and toxic metals in biological samples (scalp hair, blood, and urine) of normal and anemic children of two age groups. Biol Trace Elem Res 2011, 141(1-3):131-149.

25. Adams JW, et al: Iron deficiency and other hypoproliferative anemias. In Harrison's Principles of Internal Medicine 16th ed. Edited by Kasper DL. New York: The McGraw-Hill Companies, Inc; 2005:586-592.

26. Glass DC, Gray CN: Estimating mean exposures from censored data: exposure to benzene in the Australian petroleum industry. Ann Occup Hyg 2001, 45:275-282.

27. Horiguchi H, Oguma E, Sasaki S, Miyamoto K, Ikeda Y, Machida M, et al: Comprehensive study of the effects of age, iron deficiency, diabetes mellitus, and cadmium burden on dietary cadmium absorption in cadmium-exposed female Japanese farmers. Toxicol Appl Pharmacol 2004, 196(1):114-123.

28. Tsukahara T, Ezaki T, Moriguchi J, Furuki K, Fukui Y, Ukai H, et al: No significant effect of iron deficiency on cadmium body burden or kidney dysfunction among women in the general population in Japan. Int Arch Occup Environ Health 2003, 76(4):275-281.

29. Tsukahara T, Ezaki T, Moriguchi J, Furuki K, Ukai H, Okamoto S, Sakurai H, Ikeda M: Effects of iron-deficiency anemia on cadmium uptake or kidney dysfunction are essentially nil among women in general population in Japan. Tohoku J Exp Med 2002, 197(4):243-247.

30. Olsson IM, Bensryd I, Lundh T, Ottosson H, Skerfving S, Oskarsson A: Cadmium in blood and urine-impact of sex, age, dietary intake, iron status, and former smoking-association of renal effects. Environ Health Perspect 2002, 110(12):1185-1190.

31. Park S, Sim C-S, Lee H, Kim Y: Blood manganese concentration is elevated in infants with iron deficiency. Biol Trace Elem Res 2013, 155(2):184-189.

32. Park S, Sim C-S, Lee H, Kim Y: Effects of iron therapy on blood lead concentrations in infants. J Trace Elem Med Biol 2014, 28(2):56-59.
33. Truska P, Rosival L, Balazova G, et al: Blood and placental concentrations of cadmium, lead, and mercury in mothers and their newborns. J Hyg Epidemiol Microbiol Immunol 1989, 33(2):141-147.

34. Radisch B, Luck W, Nau H: Cadmium concentrations in milk and blood of smoking mothers. Toxicol Lett 1987, 36(2):147-152.

35. Centers for Disease Control and Prevention (CDC): Fourth National Report on Human Exposure to Environmental Chemicals. 2013. http://www.cdc. gov/exposurereport/pdf/FourthReport_UpdatedTables_Sep2013.pdf Accessed 5 October 2013.

36. ATSDR: Toxicological Profile for Cadmium. Atlanta, GA: Agency for Toxic Substances and Disease Registry; 2008.

37. Kim Y, Lee B-K: Iron deficiency increases blood manganese level in the Korean general population according to KNHANES 2008. Neurotoxicology 2011, 32(2):247-254.

38. Bellinger DC: Prenatal exposures to environmental chemicals and children's neurodevelopment: an update. Saf Health Work 2013, 4(1):1-11.

39. Kim Y, Kim JW: Toxic encephalopathy. Saf Health Work 2012, 3(4):243-256.

40. Karki $P$, Lee $E$, Aschner M: Manganese neurotoxicity: a focus on glutamate transporters. Ann Occup Environ Med 2013, 25:4

41. Maguire JL, Salehi L, Birken CS, Carsley S, Mamdani M, Thorpe KE, et al: Association between total duration of breastfeeding and iron deficiency. Pediatrics 2013, 131(5):e1530-1537.

42. Dee DL, Sharma AJ, Cogswell ME, Grummer-Strawn LM, Fein SB, Scanlon KS: Sources of supplemental iron among breastfed infants during the first year of life. Pediatrics 2008, 122(Suppl 2):S98-104.

43. Gabay C, Kushner I: Acute-phase proteins and other systemic responses to inflammation. N Engl J Med 1999, 340(17):448-454.

doi:10.1186/2052-4374-26-3

Cite this article as: Park et al:: Iron Deficiency is Not Associated with Increased Blood Cadmium in Infants. Annals of Occupational and Environmental Medicine 2014 26:3

\section{Submit your next manuscript to BioMed Central and take full advantage of:}

- Convenient online submission

- Thorough peer review

- No space constraints or color figure charges

- Immediate publication on acceptance

- Inclusion in PubMed, CAS, Scopus and Google Scholar

- Research which is freely available for redistribution 